\title{
ACE2 receptor, TRL-4 and SARS CoV-2: Do long acting opioids and opioid antagonists have potential for therapy?
}

\author{
Marie Eagleton ${ }^{1}$, Siobhan Stokes $^{1}$, Fiona Fenton ${ }^{1}$, and Eamon Keenan ${ }^{2}$ \\ ${ }^{1}$ HSE National Drug Treatment Centre \\ ${ }^{2}$ HSE Addiction Services
}

June 25, 2021

\begin{abstract}
Despite the advent of a vaccine, broadening the arsenal of drugs effective in the treatment and prevention of COVID-19 disease remains critical in the global effort to control the SARSCoV2 pandemic. Opioids and opioid antagonists may have a role in treating and in the prevention of this disease based on a number of observations: an unexpectedly low incidence of COVID-19 has been observed in patients treated for opioid dependency with long acting opioid drugs such as methadone; opioids bind to the ACE2 transmembrane protein, a molecule that is widely considered to be main host cell receptor for SARS CoV2 cell entry; opioids have systemic immunomodulatory effects which may influence the response to the virus; studies aimed at repurposing drugs for treatment of COVID-19 have identified that opioids have therapeutic potential and finally there are ongoing trials of some of these drugs. The interaction of long acting opioids or opioid antagonists with the ACE2 receptor and the possible effects on TLR4 function in SARS CoV2 infection should be given serious consideration when developing effective therapies.
\end{abstract}

Note an updated version of this preprint is under review with the British Journal of Anaesthesia

Note: An updated version of this preprint is under review with the British Journal of Anaesthesia

\section{Hosted file}

hypothesis for submission.pdf available at https://authorea.com/users/385780/articles/500996ace2-receptor-trl-4-and-sars-cov-2-do-long-acting-opioids-and-opioid-antagonists-havepotential-for-therapy

Note An updated version of this preprint is under review at the British Journal of Anaesthesia 